\title{
Mutfak Çıkmazı'nda Felsefi Bir Eylem Olarak Yemek Yapmak ve Yemek Yemek
}

\author{
Şener Şükrü YİĞİTLER*
}

Öz

Yemek yapmak ve yemek yemek, günlük hayatın ayrılmaz parçalarıdır. Hayati oldukları kadar verdikleri zihinsel/bedensel tatmin duygusuyla da insanı besleyen, yaşamı zenginleştiren bu eylemler, sanatsal ürünlere malzeme olmuşlardır. Edebiyatta da mutfaktaki hazırlıklara, yemek sofralarına, eğlence masalarına çok fazla rastlanmaktadır. Dünya edebiyatındaki kurmaca örneklerin çokluğu yanında Türk edebiyatında yemek konusu çoğu zaman kurmaca dışı alanda yoğunlaşmıştır. Türk yazarlarının başta Ramazan sofraları olmak üzere, hemen her mevsimde ve belli mekânlarda bulunabilecek yiyecek ve içeceklerle ilgili yazdıkları hacimli bir külliyat oluşturmaktadır. Mutfak Çıkmazı (1960), kurmaca dışı sofralar bir yana bırakılırsa, yemek yapmak ve yemek yemek konusunda Türk edebiyatında akla gelen en önemli eserlerden biridir. Bu romanda yemek yapmak, ilk bakışta, içine düştügü yalnızlık ve başarısızlık duygusuyla kendini bütün hayattan soyutlayan bir hukuk öğrencisinin anlamsız tutkusu gibi görünmektedir. Dönemin edebî ürünlerinden de izlendiği üzere, Tahsin Yücel'in ilk romanı olan Mutfak Çıkmazı'nın yayımlandığı 60'lı yılların başında, Türk entelijansiyasının ilgisini çeken konuların başında varoluşçuluk ve yabancılaşma gelmektedir. Varoluşçu eserlerin Türk edebiyatçıları üzerinde fazlasıyla etkili olduğu bu dönemde Türk edebiyatında da benzer izlekler işlenmeye başlamıştır. Tahsin Yücel'in, çağdaş Fransız edebiyatının en önemli romanlarından Yabancı'daki hayata yabancılaşmış, uyumsuz karakteri Mersault'nun bir benzerini yarattı̆̆ Mutfak Çıkmazı'nda romanı için seçtiği yemek temasına birtakım felsefi anlamlar yüklediği görülmektedir. Konuyla ilgili pek çok önemli kurmaca eserde iyileştirici, zevk verici ve birleştirici yanları öne çıkarılan yemek yapmak ve yemek yemek eylemlerinin, Tahsin Yücel tarafından oldukça farklı biçimde ele alındığı dikkat çekmektedir. Romanın içeriksel zeminini yemek yapmak teması, düşünsel altyapısını kişinin çevresine duyduğu kayıtsılık ve tiksintinin bir sonucu olan yabancılaşma düşüncesi oluşturmaktadır.

Bu makalede, Tahsin Yücel'in Mutfak Çıkmazı romanının ana temaları olan yemek yapmak ve yemek yemek izleklerini, edebiyatta alışılmışın dışında olarak yalnızlaştırıcı ve yabancılaştırıcı bir felsefi eylem olarak ele alması ve romanın içeriksel/düşünsel bütünlüğünün varoluşçu felsefeyle uyumu tartışılmaktadır.

Anahtar Kelimeler: Tahsin Yücel, Mutfak Çıkmazı, yemek yapmak, yemek yemek, varoluşçuluk, yabancılaşma

\footnotetext{
* Arş. Gör. Dr., Bitlis Eren Üniversitesi, Fen-Edebiyat Fakültesi, Türk Dili ve Edebiyatı Bölümü, Türkiye. Elmek: ssyigitler@gmail.com
} 


\title{
Cooking and Eating as a Philosophical Act in Tahsin Yücel's Mutfak Çıkmazı
}

\begin{abstract}
Cooking and eating are integral parts of daily life. Both vital and nurturing for human life and enriching life experience with mental and physical sense of satisfaction, these actions have also been a subject of works of art. Culinary preparations, dining tables and banquets are also often treated as literary themes. While world literature abounds with fictional works on these themes, Turkish literature rather focuses on non-fiction in addressing food as a theme. Turkish authors have created a voluminous corpus on Ramadan tables in particular, and foods and drinks available in each season and in particular venues in general. Beside non-fictional tables, Mutfak Ç1kmazı (i.e. Kitchen Dead End, 1960) is one of the primary works about cooking and eating in Turkish literature. At first glance, this novel features cooking as the futile passion of a law student who isolates himself from everything due to his feelings of loneliness and sense of failure. As is evident in almost all contemporary literary works, existentialism and alienation were among the primary subjects of interest among Turkish intellectuals in the early 1960s, when Tahsin Yücel published Mutfak Çıkmazı as his first novel. In his work, Tahsin Yücel brought to life a character very similar to Mersault, the alienated non-conformist protagonist of The Stranger, i.e. one of the most prominent works of modern French literature. The author seems to have assigned a set of philosophical meanings to food as the main theme of this work. While many prominent works of fiction on the subject highlight the therapeutic, gratifying and uniting aspects of cooking and eating, Tahsin Yücel sees the subject in a rather different light. The novel's content mainly revolves around the theme of cooking, and its intellectual background focuses on the notion of alienation, which originates from one's feelings of apathy and repulsion for their environment.

Emphasizing the fact that Tahsin Yücel treats cooking and eating, i.e. the main themes of his novel Mutfak Çıkmazı, as isolating and alienating philosophical acts, which is an original literary contribution, this paper discusses the accord between the existentialist philosophy and the contextual/ intellectual integrity of the novel.
\end{abstract}

Keywords: Tahsin Yücel, Mutfak Çıkmazı, cooking, eating, existentialism, alienation 


\section{Giriş}

Yemek, insanoğlu için hayatta kalmanın en temel unsurlarından biridir. Yiyeceklerin başta bir 1sı kaynağı uygulanması olmak üzere pek çok yöntemle yenmeye hazır hale getirilmesi işlemi şeklinde tanımlanabilecek yemek yapmak günlük bir eylem olmanın ötesinde kültürün asli bir parçasıdır. İlk insanların yiyecekleri daha kolay yenebilir hale getirmek için ateşi kullanmalarından bugüne bu konuda kaydedilen gelişme, yemek yapmanın ve ustalıkla yürütülen bir süreç sonunda ortaya çıkan ürünün yenmesinin birçok insan tarafından vazgeçilmez bir zevk ve tutku olarak görülmeye başlandığını açıkça ortaya koymaktadır. Yapılacak yemekte kullanılan malzemelerin hazırlanmasından sofraya gelen son ürünün sunumuna kadar pek çok değişik süreci kapsayan yemek yapmak zamanla insanlar için bir ihtiyaç olmanın ötesine geçerek gastronomi bilgisinin, el becerisinin, damak tadının ve göz zevkinin buluştuğu bilimsel ve sanatsal bir faaliyet haline gelmiştir. Yemek kültürü ve tarihçiliği araştırmaları, yemeği popüler kültürün en gözde alanları içine katmıştır (Samancı 2012: 107-120; Samancı 2014: 27-40). Bugün, hızlı tüketim mantığını ilke edinen fast-food zincirlerinden geleneksel yemek kültürünün son kaleleri olarak görülen esnaf lokantalarına, çeşitli kimyasal ölçümlerin kusursuz damak tadını yakalamak için hizmete koşulduğu füzyon mutfaktan orijinal mekânlarda yine orijinal tariflerle müşterilerini sultanların ve kralların sofralarına oturmayı vaat eden geleneksel mutfaklara yemek, popüler kültürün ayrılmaz bir parçası olmaya devam etmektedir (BeardsworthKeil 2011: 125-208)

Popüler olsun veya olmasın, kültürün içinde yer alan her konu, düşünsel bir süzgeçten geçirilerek derinleştirilmekte ve boyutlandırılmaktadır. Yemek yapmak ve yemek yemek, çoğunlukla, kültürel alanın ince zevklilik, yaşamdan keyif alma, kendine zaman ayırma, kendini tanıma/iyileştirme ve başkalarıyla iletişim kurma gibi olumlu çağrışımlarla yüklü, incelikli, yaratıcı, sağaltıcı ve birleştirici mecrasına konumlandırılmaktadır. Geleneksel formatın sıkı sıkıya takip edildiği, yemek tariflerinden ve mutfak tekniklerinden mürekkep Türkçe yemek kitabı 
ve programların aksine, son dönemde bütün dünyada yemek yapmak ve yemek yemek üzerine düşünce üreten Laurie Colwin'in Home Cooking (1988), Ruth Reichl'ın Comfort Me with Apples (2001), editörlüğünü Jenni Ferrari-Adler'in yaptığ 1 Alone in the Kitchen with an Eggplant (2007) gibi mutfak anıları ve anekdotlarıyla dolu yemek kitapları ve üçü de Türkçeye çevrilen ve filme çekilen Laura Esquivel'in Acı Çikolata (1989), Joanne Harris'in Çikolata (2000), Elizabeth Gilbert'in Ye Dua Et Sev (2006) adlı romanları, mutfağın, yemek sofralarının ve özellikle de yemek yapmanın bireyselleştirici, iyileştirici ve paylaşımcı yanını öne çıkaran eserler olarak ilk akla gelenlerdir.

\section{Dünya Edebiyatında Yemek}

Yemek, popüler kültür ve popüler edebiyatın olduğu kadar, yüksek edebiyatın da ilgisini çeken bir konudur. Tanpınar'a göre, Le Sage'ın 1715-1735 yılları arasında yayımlanan pikaresk romanı "Gil Blas'tan beri yemek romanın mühim unsurlarından olmuştu(r) (1988: 461). Dünya edebiyatının pek çok güçlü örneğinin en ince ayrıntılarına girerek veya sadece ismen zikretmekle yetinerek yiyecek ve içeceklere bir şekilde yer vermesi yemeğin edebî potansiyelleri hakkında bir ilk izlenim edinmeye yardımcı olmaktadır. Dinah Fried dünya edebiyatının en fazla akılda kalan yemeklerinden bir seçkiyle meydana getirdiği Fictitious Dishes (2014) adlı albümünde kitaplara dair hatırladığı en canlı anılarının, karakterlerin yedikleri yemeklerden oluştuğunu kaydetmektedir (2014: 10). Gerçekten de, bir ada üzerinde tek başına hayatta kalma konusunda pek çok hayat kurtarıcı bilgilerle bezeli Robinson Crusoe'da (1719) Defoe'nun avcılık/toplayıc1lı̆a dair verdiği gerçekçi betimlemeler bu eserin neden ilk realist roman olarak kabul edildiğini daha iyi ortaya koymaktadır. Robinson gibi bir denizci olan İsmail'in yoldaşlaryyla beraber uzun deniz yolculukları boyunca sahip oldukları kısıtlı beslenme imkânları, fantastik bir deniz canavarının hikâyesinin anlatıldığı Moby Dick'in (1851) gerçekçi ayrıntıları arasındadır. Göz alıcı oldukları kadar gerektirdikleri katı görgü kuralarıyla samimi ve doğal olmaktan uzak Bovary çiftinin dügünündeki servis masalarının aksine, Alis Harikalar Ülkesinde'deki (Alice in Wonderland, 1865) kaotik çay partisinin düzenlendiği masa tuhaflığ 1 ve düzensizliğiyle okurlara eğlence ve rahatlık vaat etmektedir. Jerome K. Jerome'un Teknede $\ddot{U}_{c}$ 
Adam (Three Men in a Boat, 1889) adlı romanı, geleneksel bir İngiliz âdeti olan beş çaylarına bolca yer veren bir başka eserdir. Kenneth Grahame'ın Sögüuttükte Rüzgâr (The Wind in the Willows, 1908) adlı klasik çocuk kitabının fabl estetiğinin çok ötesindeki hayvan kahramanları da Bay Porsuk'un evinde ağızlarına layık bir ziyafet çekerlerken hayvanlar arasında kendiliğinden oluşan dostluk, sofrada bulunan herkesin hâl ve hareketlerine yansıyan rahatlık ve Bay Porsuk'un evinin sıcaklığı olduğu gibi okura geçmektedir.

$\mathrm{Bu}$ örnekler dışında, edebiyatın devleri arasında zikredilen Marcel Proust'un Swann'ın Yolu (1913) adlı romanında birer geçmiş zaman yadigârı gibi özlemle anlattığı Madeleine kurabiyeleri, James Joyce'un Ulysses'te (1922) Leopold Bloom'a iştahla ve gürültüyle yedirdiği sakatat yemekleri ve İngilizlerin yemek konusunda Fransızların yanında hiçbir iddiasının olamayacağını itiraf kabilinden dile getiren Virginia Woolf'un Bayan Ramsay'e misafirleri için hazırlattığ bir Fransız yemeği olan Boeuf en Daube ve daha bunun gibi yüksek edebiyatın en seçkin örneklerinden verilebilecek yüzlerce yemek, edebiyat dünyasının en yetenekli isimlerinin hayatın en temel konularının yanı sıra mutfağa da tutkuyla girdiklerini göstermektedir.

Ara bir sonuç olarak, dünya edebiyatında yemek yapmak ve yemek yemekle ilgili anlatılarda mutfaklardan ve yemek sofralarından yayılan en güçlü duygunun, insanın temel ihtiyacının karşılanmasından doğan haz ve mutluluk olduğu söylenebilir. Olumlu çağrışımlarla yüklü bu eylemler, edebiyattan resim sanatına kadar pek çok yaratıcı alanda insanları sevindiren, birleştiren, paylaşıma ve iletişime sokan bir unsur olarak kullanılmaktadır. Yemeklerin pişip taştığı mutfaklarla zengin sofraların anlatıldığı eserlerde bu tespit fazlasıyla doğrulanmakla birlikte, kısıtlı yiyecek kaynaklarının söz konusu olduğu Oliver Twist (1838), Germinal (1885), Gazap Üzümleri (Grapes of Wrath, 1939) gibi romanlarda da yemek ve içmenin insanlar için ortak bir umuda işaret ettiği görülmektedir. Yemek, bu defa da, hayali bile aç insanları bir araya getirmeye yeten birleştirici bir amaçtır. Bu eserlerde roman karakterlerinin ender ele geçirdikleri bir şeyler yeme firsatlarında gösterdikleri aşırı tepkiler, sofraya egemen olan neşe ve çılgınlık hali bu durumun kanıtıdır. Knut Hamsun'un Açlık'ında (Sult, 1890) roman boyunca adsız başkahramanın karnını ve zihnini kemiren açlığın 
yanı sıra bütün romana yayılan avarelik, yalnızlık ve ümitsizlik duygusu, yemek yemenin biyolojik/fizyolojik ihtiyaçların karşılanmasının ötesinde anlamları olduğunu ortaya koymaktadır.

\section{Türk Edebiyatında Yemek}

Dünya edebiyatında durum böyleyken, Türk mutfağının ve sofrasının bütün zenginliği, lezzetleri ve çeşnileriyle Türk edebiyatında görünür olduğunu söylemek mümkün değildir. Türk romanında bu konunun da, diğer pek çok konu gibi, Batılılaşma çerçevesinde ele alındığını belirtmek gereklidir. Değişen sofra âdâbı, yer sofralarından masalara geçiş, çatal-bıçak kullanılması gibi konular hep bir Doğu-Batı kıyaslaması ve medeniyet çatışması ekseninde ele alınmıştır. Edebiyatın alanına yemeklerinin kendisinin değil, onları yeme biçiminin, sofra/masa düzeninin ve sofradaki âdâb-1 muâşeretin girdiği söylenebilir. Bu bir bakıma, Türk modernleşmesinin bir bütün olarak "içerik"ten çok, "şekil”e verdiği önemin yemek sofralarındaki edebî yansımasıdır.

Mutfağın ve bütün süreçleriyle yemek yemenin yenileşme devri Türk edebiyatındaki işlenişine baktığımızda yemek sofralarında da modernleşme konusunda bir gayret dikkati çekmektedir. Türk edebiyatında birçok konuda olduğu gibi alafranga-alaturka sofralar arasındaki farklara işaret eden ilk isim Ahmet Mithat Efendi'dir. Doğu'daki yemekleri Batı yemeklerine kıyasla çok lezzetli bulmasına rağmen yenme biçiminin rahatsız edici olduğunu ifade eden Ahmet Mithat, alafranga sofra düzeni ve âdâbını "Batı'dan aldığımız âdetlerin en güzeli” şeklinde tavsif etmektedir (Okay 2008: 166). Ahmet Mithat Efendi bu karşılaştırmaları Avrupa'daki izlenimlerinden oluşturduğu Avrupa'da Bir Cevelân (1890), Avrupa Âdâb-1 Muâşereti yahut Alafranga (1896) adlı gezi-anı türü eserlerinde ve ikinci kitapla aynı yıl yayımladığı Taaffüf adlı romanında konu etmiştir. Taaffüf'te Batılılaşma konusunda mutedil ve uzlaşmacı bir yol izleyen Rasih ve Seniha, yerli mutfağın lezzetli yemekleriyle Batılı sofra düzeni ve âdâbını uyumlu biçimde birleştirmiş bir çifttir (Ahmet Mithat 2000: 151). Ahmet Mithat gibi, alafrangaalaturka sofralar arasındaki farklılığa işaret eden Hüseyin Rahmi Şıpsevdi'de (1911), makul düzeydeki Batılılaşmanın çizgisini aşan züppe tipinin başarılı bir eleştirisini vermektedir. Tanzimat dönemi edebiyatında, Batılı usulde kurulan şık 
sofralara yer veren Araba Sevdası (1896), Sergüzeşt (1888), Eylül (1901) romanlarında alafranga sofraların lehindedir. Bunun gibi, Kiralık Konak (1922), Kırlk Hayatlar (1924), Aşk-ı Memnu (1925), Ankara (1934), Üç İstanbul (1938), Hep $O$ Şarkı (1956) gibi Cumhuriyet dönemi romanlarında Avrupa tarzı gösterişli yemek masaları anlatılmıştır. Yenileşme devri Türk edebiyatının erken dönemlerinde yemek sofraları Batılılaşmanın bir sembolü olarak görev görmüşlerdir. Verilen örneklerden de anlaşıldığı üzere, Türk yazarlarının yemeklerle değil, yemeklerin sergilendiği sofralarla ilgilendiği ortadadır. Kırkoğlu'nun da ifade ettiği gibi, "bir hakikatin korunup taşınmasına ilişkin simge işlevi”ni (2004: 87), burada Dünya edebiyatından verilen birçok örneğin aksine, yemekler değil, yemek sofraları üstlenmiş görünmektedir.

Bu bölümün başında kaydedildiği gibi, Türk yazarlarının yemek hakkındaki kurmaca-dışı yazıları daha zengin bir içerik sunmaktadır. "Kana kuvvet, göze fer, batna ciladır çorba" dizesinin sahibi Ahmet Rasim, başta Ramazan sofralar1 olmak üzere İstanbul'un yemek kültürü konusunda değerli bilgiler vermiştir. Ahmet Rasim dışında, Refi' Cevat Ulunay, Ercüment Talu, Fikret Adil, Mahmut Yesari, Sermet Muhtar Alus, Semih Mümtaz S., Refik Halit Karay, Süleyman Çapanoğlu ve kelimenin gerçek anlamıyla bir "gurme" olan Ahmet Haşim gibi edebiyatçıların yemek konusunu işledikleri görülmektedir (Gürsoy 2013: 133). Hilmi Yavuz da özel hayatlarıyla yemek konusunda son derece tutkulu isimler arasında Yahya Kemal'i zikretmektedir (2018: 8). Türk edebiyatında çok fazla örneği bulunmayan an1-yemek türündeki kitabı Oburcuk Mutfakta'da Selim İleri, "Behçet Necatigil' in kimi şiirlerinden, Orhan Kemal'in unutulmaz 'Çikolata' öyküsünden, Muzaffer Buyrukçu'nun öyküsünde geçen sabah kahvaltısından” söz etmektedir (2010: 5).

Yenileşme devri Türk edebiyatının estetik/edebî bakımdan ilk başarılı örneklerini 1950'li yıllarda vermeye başlamasıyla yemekler, bütünün parçasını oluşturdukları sofraların önüne geçerek, kurmaca eserlerde daha görünür hale gelmişlerdir. Ahmet Hamdi Tanpınar Huzur'da (1949) bir ritüel estetiğiyle verdiği ve "lüfer bayramı" diye adlandırdığı balık avına dair gözlemlerini 27 Aralık 1958 tarihli, "Lodos, Sis ve Lüfere Dair” başlıklı mektubunda bu görüşlerini Hasan Âli Yücel'le de paylaşmıştır (1997: 65). Ona göre Boğaz' daki lüfer mevsimi sadece bir balık avı değil- 
dir; sonbaharın gelişiyle zengin-fakir bütün mutfaklarda baş tacı edilen bir yiyeceğin Osmanlı'dan bu yana bir zevk ve damak tadı birikimiyle İstanbul'u büyük ve şenlikli bir sofraya çevirmesidir. Nuran'ın dayısı Tevfik Bey gibi balık konusunda gurme Boğaziçi sakinleri için kurulacak sofraların ana malzemesi yılın bu zamanı bellidir. Türk edebiyatının yemeyi içmeyi seven kurmaca kişileri arasında akla ilk gelenlerden bir diğeri Vüsat O. Bener'in Havva adlı küçük besleme karakteridir. Havva, evin hanımı ve kızının deneme amacıyla önüne koydukları her şeyi yiyen, "pis boğazlığı yüzünden” başına türlü belalar açılan, “doymak bilmez”, kimsesiz ve yoksul bir köylü kızıdır (Bener 2015: 34, 32). Son nefesinde "baklava" ister ve ölür. (2015: 35). Türk edebiyatının bir başka yemek meraklısı Abdülhak Şinasi Hisar'ın Çamlıca'daki Eniştemiz (1944) romanının başkarakteri, yazarın tasviriyle belli dönemlerde evin mutfağını muhasara altına alan Hacı Vamık Bey de burada anılmalıdır. Eşi, onun sonu gelmez müdahalelerinden bezerek önce mutfağı, ardından evi tümüyle terk eder. Bunun gibi, mutfak-kadın ilişkisi üzerinden değerlendirilebilecek bir başka kadın karakter Sevgi Soysal'ın Tante Rosa'sıdır. 16 öyküden oluşan Tante Rosa'nın (1968) aynı adlı başkarakteri, Havva'nın aksine, her Pazar kaz kızartmalarının, elma pastaların piştiği ve kurduğu düzeni temsil eden mutfağı ardına bakmadan terk eder. Erkek egemen kültürde kadının "doğal çalışma alanı" olarak görülen ev mutfaklarının tersine, lokanta, otel ve lüks yalı, malikânelerin mutfaklarında erkek aşçıların egemenliği söz konusudur. Vasıf Öngören'in 12 Mart Darbesi ve 15 Haziran Büyük İşçi Direnişi’ni eserin fonuna yerleştirdiği Zengin Mutfağı (1977) adlı oyunu, mutfağı sınıfsal mücadelenin mekânı olarak işler.

Ancak bu eserlerde, yukarıda dünya edebiyatından verilen örneklerde olduğu gibi yemeklerin tatları ve kokularıyla edebiyata girdiklerini söylemek mümkün değildir. Dikkati çeken en önemli değişim, okuyucu karşısına zengin sofralarda çıkan yemeklerin, "düşük gelir, orta gelir düzeyinde” (İleri 2010: 5) sunulmaya başlanmasıdır. Yemek çeşitliliğiyle okuyucunun hayal gücünü harekete geçirilmesinden veya yemek adlarının ve malzemelerinin dökümünün yapılmasından çok, bir eylem olarak yemek yapmak hâlâ mutfaktadır; okuyucunun önüne çıkarılmamıştır. Bu genellemenin başarılı bir istisnası sayılabilecek bir sahneye Hasan Ali Toptaş'ın Heba (2013) adlı romanında rastlanmaktadır. Toptaş, bu romanında, bir anda yapmaya karar verilen bir "şaştım aşı" olmadığını söylediği kuru fasulye 
pişirmenin en ince noktalarını ve genel anlamda yemek yapmanın anlamını Ebecik adlı yaşlı bir kadının ağzından halk bilgeliğiyle iç içe geçmiş bir ses, görüntü ve lezzet zenginliğiyle verir (2013: 79-80).

\section{Bir İlk Roman Mutfak Çıkmazı}

Tahsin Yücel'in aynı adlı öyküsünü genişleterek romanlaştırdığı Mutfak Çıkmazı 1960'ta yayımlanmıştır. O yıla kadar yayımlanan Uçan Daireler (1954), 1956 Sait Faik Hikâye Armağanı'na değer görülen Haney Yaşamalı (1955) ve 1959 Türk Dil Kurumu Öykü Ödülü’ne değer görülen Düşlerin Ölümü (1958) adlı öykü kitaplarıyla birlikte yazarın kendine özgü dil ve üslubu yarattı̆̆ı süreci imleyen Mutfak Çıkmazı, roman kurgusuna sonradan uydurulmuş yapısıyla yazarın diğer romanlarının yanında zayıf bir eserdir. Kuşkusuz bir başka araştırmanın konusu olabilecek bu durumu, 'öykü’nün, içini doldurmaya çalıştığ 'roman' kabının dışına taşması şeklinde özetleyebiliriz. Anlatım ve kurguda görülen belli başlı aksaklıklarda ve kullanılan temalarla savunulan düşünce sistemi arasındaki uyumsuzlukta eserin bir ilk dönem eseri olmasının payı da, kuşkusuz, büyüktür. Ancak romanın bir bütün olarak başarısını aşağı çeken bu etmenlerin anlaşılması için romanın kaleme alındığ 1 dönemde Türkiye'deki sanat ve düşünce ikliminin doğru analiz edilmesi gerektiği kanaatindeyiz.

Jale Özata Dirlikyapan “Türk Öykücülüğünde 1950 Kuşağı” alt başlıklı Kabuğunu Kıran Hikâye (2010) adlı incelemesinde söz konusu öykü geleneğinin en sık kullandığı temaları tespit etmeye çalışırken, o yıllarda Batı felsefesinde "varoluşçuluk" ve sanat dünyasında "gerçeküstücülük" akımlarının Türk öykücüleri üzerinde etkisinin belirleyici olduğunu kaydetmektedir. Yusuf Atılgan, Orhan Duru, Ferit Edgü, Leyla Erbil, Özcan Ergüder, Bilge Karasu, Feyyaz Kayacan, Onat Kutlar, Erdal Öz, Demir Özlü ve Adnan Özyalçıner'in "varoluşçuluğun etkisiyle hiçlik, cinsellik, intihar, sıkıntı, suç gibi konular"'n (Dirlikyapan 2013: 110) sıkça görüldüğü öykülerinde anlamsızlık ve bunalım genel atmosferi oluşturmaktadır. Öte yandan, gerçeküstü-absürd bir üslubun öykülerin estetiğini kurduğu gözlemlenmektedir.

Asım Bezirci, varoluşçu felsefenin en önemli teorisyeni Jean Paul Sartre'dan çevirdiği Varoluşçuluk adlı kitabın ön sözünde varoluşçuluğun tan1- 
m1, kökenleri, çeşitleri, eleştirisi, Türkiye'deki yansımaları ve Türkçedeki Sartre çevirileri hakkında ayrıntılı bilgiler vermektedir. Varoluşçuluğun söz konusu kuşak üzerindeki etkilerini göstermesi bakımından faydalı bilgiler içeren ön sözün “Türkiye'de Varoluşçuluk” başlıklı bölümünde dönemin dergilerinde varoluşçulukla ilgili çıkan yazıların listesinin yanı sıra 1950 kuşağı öykücülerinin birincil kaynaklardan yaptıkları çevirilere yer verilmektedir. Bu çevirilerin yanında, yaşanan tartışmalarda Peyami Safa, Atillâ İlhan, Şerif Hulûsi, Başar Sabuncu'nun varoluşçuluk felsefesini eleştiren yazılar yazdıkları, Muzaffer Erdost, Osman Oğuz, Ferit Edgü ve Fikret Ürgüp'ün bu eleştirilere cevap verdikleri görülmektedir. Bu dönemde en fazla dikkat çeken yazı ise Demir Özlü'nün Yeni Ufuklar dergisinin 127. sayısında (Aralık 1962) çıkan "Bunalım Yazınını Savunu" başlıklı yazısıdır (Sartre 2018: 17-18).

1950’li yıllarda edebî çevrelerde aldığı ödüllerle adını duyuran Tahsin Yücel'in, Dirlikyapan'ın incelemesinde, Bezirci'nin ayrıntılı ön sözünde ve konuyla ilgili diğer kaynaklarda zikredilmemesi dikkati çekmektedir. Bunun belli başlı nedenleri arasında, adları geçen öykü yazarlarının eserlerinin yayımlandığ1 50'li yıllarda, Tahsin Yücel'in, 1950 kuşağı öykücülerinin hızlanan kentleşme bağlamında bireycilik, öznellik ve iç yaşantı gibi konularla ilgilendikleri bir edebî ortamda, daha geleneksel bir öykücülük anlayışı benimsemiş olması başta gelmektedir. Bununla birlikte, Elbistan doğumlu yazarın Galatasaray Lisesi ve İstanbul Üniversitesi Fransız Dili ve Edebiyatı Bölümü’nde aldığı eğitimin ve burada başladığı akademik hayatının, çoğu küçük kentsoylu ailelere mensup 1950 kuşağı öykücülerinin muhtemelen daha erken yaşlarda ve dolaysız yollardan edindikleri edebî zevk ve kültürel altyapıyı eğitim yoluyla kazandırmış olması ihtimal dâhilindedir. Tahsin Yücel'in yazarlık hayatı boyunca bütün eserlerinde görülen baskın akademik/teorik niteliğin bununla doğrudan ilgisi olduğu düşünülebilir. Batılı düşünce ve sanat akımlarının 1950 kuşağı öykücülerinin eserlerinde nispeten özümsenmiş ve doğal izlenimi veren kişisel deneyim ve ilgileriyle pekiştirilmiş etkisinin, bir ilk roman olan Mutfak Çıkmazı'nda nispeten teorik düzeyde kalmasının nedenini Tahsin Yücel'in akademisyen yönünde aranmak gerekmektedir. Bütün bu etmenler bir arada düşünüldüğünde, Tahsin Yücel'in tipik bir 1950 kuşağı öykücüsü olmadığı görülmektedir. Bununla birlikte, varoluşçuluğun en 
önemli kavramlarından olan "yabancılaşma ve kimlik bunalımı(nı), modernizmin ve sonrasında da postmodernizmin etkisiyle Türk edebiyatını besleyen önemli bir kaynak" (Ulutaş-Ulu 2015: 2109) olarak kullandığı tespit edilen eserlerden oluşan uzun bir liste içinde, Tahsin Yücel'in 1960 tarihli Mutfak Çıkmazı romanı dâhil 1990 ile 2000'li yıllarda peş peşe yayımlanan bütün romanlarının zikredildiğini ayrıca kaydetmek gerekmektedir.

\section{Bir Çıkmaz Olarak Mutfak}

Yabancılaşma ve insan hayatının anlamsızlığı temalarını çarpıcı biçimde işleyiş̧leriyle dünya edebiyatına damgasını vuran iki önemli roman olan Dönüşü̈m (Metamorphosis, 1915) ve Yabancı'nın (L'étranger, 1942), 1950 kuşağı öykücüleri gibi Tahsin Yücel'i de fazlasıyla etkilediği Mutfak Çıkmazı'nın tema, içerik, karakter, üslup ve özellikle mekân tercihlerinden anlaşılmaktadır. "Mutfağın evin kalbi olduğu modern öncesi dönemden apartman boşluğuna bakan mutfaklara geçilmesinin" (Bora 2009: 71) Tahsin Yücel'in, mutfağı bir çıkmaz olarak tahayyül etmesini sağlayan sosyolojik ve kültürel nedenleri desteklediği ortadadır. Ancak bu mimari dönüşüm, romandaki söz konusu kurgusal ve mekânsal tercihi tümüyle açıklayacak kadar güçlü bir etken değildir. Zira, dünya edebiyatlarından verilen örneklerde de görüldüğü gibi, mutfağın “çıkmaz” sözcüğünün taşıdığı olumsuz çağrışımlarla yüklü bir mekân olarak işlenmesi söz konusu değildir. Ne var ki, Mutfak Çıkmazı'nda mutfak ile çıkmaz arasında kurulan ilişki, romandaki mekânların çağrışımsal anlamlarıyla değil, olayların gelişimiyle sağlanmıştır. Romanın isminden içeriğine kurulan bağlantısında olay örgüsünün mutfağı bir “çıkmaz”a dönüştürmek üzere sahne sahne planlanması bu yüzdendir.

Başkarakter İlyas Divitoğlu'nun ölüm haberi ve acısıyla başlayan romanın olay halkalarını düz bir zincir şeklinde dizildiğinde romanın konusu şu şekilde özetlenebilir: Osmanlı döneminin köklü ve zengin ailelerinden Divitogulları zamanla bütün gücünü kaybetmiştir. Cumhuriyet'in ilk yargıtayında üye olan dede Divitoğlu'nun erken ölümüyle bütün gözler torun İlyas'a çevrilir. İlyas Divitoğlu'nun iyi bir eğitim alıp dedesi gibi yargıtay üyesi olması ve soylarını eski günlerine kavuşturması için Divitoğlu sülalesi adeta seferber olur. Maddi imkânsızlıklara rağmen, akrabaların da desteğiyle İlyas lise eğitimini almak üzere 
İstanbul'a gönderilir. Liseyi birincilikte bitiren İlyas Hukuk fakültesine başlar. Burada Emel adında bir kızı sever. Ona evlilik teklif eder ancak reddedilir. Aldığ 1 ret cevabı, ailenin beklentileri, bir türlü kurtulamadığı devamlı parasızlık ve yalnızlıkla birleşerek İlyas'ı bunalıma sürükler. Bir tesadüf eseri karşılaştı̆̆ bir adamdan yemek yapmanın ekonomik faydaları hakkında dinlediklerinin etkisiyle yemek yapmaya karar verir. Bütün parasını gerekli eşya ve malzemelere harcayan İlyas'ın evi kısa sürede tam donanımlı bir aşçı mutfağına dönüşür. Yaptığı yemeklerle aşçılık konusunda doğuştan yetenekli olduğunu gösterir. Bir gün bir partide tanımadığı bir kadından tesadüfen duyduğu coq-au-vin adlı bir Fransız yemeğini saplantı haline getirir. Yaptığı yemekleri bayağı bulmaya, sıkılmaya başlar. Bunu fark eden arkadaşı Selami, yalnızlığını gidermesi için Necdet adında bir arkadaş1nın kedisi Aliye'yi İlyas'a getirir. Saplantısı bir türlü dinmeyen İlyas coq-au-vin tarifini öğrenmek için her yolu dener. En sonunda bu yemeğin tarifinin de içinde olduğu Fransız yemek kitaplarını bulur. Bu kitapları almak için bütün parasını harcar. İlyas ailesinden gelecek maddi destek için memlekete yalan yanlış mektuplar yazar. Ziyaretine gelen bir yakınına Emel adlı bir kadınla kısa sürede evleneceği yalanı söyler. Bu esnada, ruhsal çöküntüsü hayli ilerleyen İlyas fakülteyi bırakır, derslere devam etmez. Yemeğe ve zevkine düşkün biri olan Selami için yemekler yapar. En iyi arkadaşı Murat, İlyas'ı yemek tutkusundan vazgeçirmeye çalışır. Emel'in evlenmeye razı oluşu da İlyas'ı çalışkanlı̆̆ 1 ve derslerdeki başarısı nedeniyle bölüme asistan olarak almayı tasarlayan hocası Orhan Bey'in çabaları da sonuçsuz kalır. İstanbul'dan kaçıp Selami'nin kız kardeşiyle evlenme ve Adana'da bir lokanta açma kararlı alır. Aliye'nin evden kaçışıyla İlyas bütün kontrolünü yitirir. Aliye'yi çaldıklarına inanarak insanlardan tiksinir. İçki ve sigara yüzünden hastalanır. Bir süredir kiralarını ödeyemeyen İlyas, ev sahibinden Murat'ın bütün ödemeleri yaptığını öğrenir. Murat yanında bir doktorla eve gelir. Emel'le evlilik kararını açıklar. İkisi, İlyas'ı saplandığı kötü hayattan çıkarmak için birlikte yaşadıkları çiftliğe aşçı olarak alırlar. İlyas'ın amcasının oğlu Mustafa, İlyas'ı bir aş̧̧ olarak karşısında görünce ailenin şerefini kirlettiğini söyleyerek silahla öldürür.

İlyas'ın yası tutulurken Mustafa'nın öldürülmesinin aile büyüklerince kararlaştırılmasıyla yukarıda sıralanan bütün bu olaylar zinciri hikâyenin başına bağlanmıştır. Biçimsel bakımdan değerlendirildiğinde romanın başkarakteri olduğu 
anlaşılan kişinin ölüm haberiyle başlayan romanın okuyucuda merak duygusu uyandırmak için ilk sayfalarda bir hamle yaptığı görülmektedir. Ancak, kuşkusuz, romanın asıl amacı okuyucuyu roman boyunca bir sonraki gelişmeyi merak ettirecek bir entrikalar zinciri kurmak değil, İlyas Divitoğlu karakterinin sonu cinayetle biten buhranlı ve saplantılı psikolojik dönüşümünü anlatmaktır. Romana egemen olan s1kıntılı, bunalımlı havanın ve yer yer absürd üslubun amacı da budur. Örneğin, İlyas Divitoğlu'nun mutfağa kapanmasına neden olan olayın anlatıldığı sahne varoluşçu eserlerde sıkça rastlanan kasvetli ve "saçma" bir estetiğin başından sonuna başarıyla kurulduğu ilgi çekici bölümlerden biridir. İlyas, Emel'in kendisini terk ettiği günün sabahında şehirde gördüğü her şeyden nefretle gezerken pencerede bir adamın sigara içişine hayranlıkla bakar. Bu adam, onun en iyi arkadaşlarından biri olan Murat'tır. İlyas işyerine girerken Murat İlyas'ın açlıktan nefesinin koktuğunu fark eder. İkisi Emel hakkında bir süre konuşurlar; daha sonra, içeri kısa boylu, şişman bir adam girer. Bu, oldukça yaşlı ancak neşeli ve konuşkan bir küçük memurdur. Adam, bir süre çektiği maddi güçlüklerin ardından kendi yemeğini yapmaya başladığını, öğlenleri lokantaya gitmediğini, on bir liraya aldığı sefertasıyla yemeklerini işyerinde yemeğe başladığını ve bu sayede yaşamından memnun olduğunu keyifle anlatır. Adamın neşesine ortak olan Murat'ın aksine, İlyas adeta taş kesilir. Kocaman gözlerle adamı izler. Adam konuştukça İlyas delirecek gibi olur. Susması için bağırır, adamın yakasına yapışır. Adam yüzünde eğreti bir gülümsemeyle anlatmaya devam eder, yemek yapmanın sanıldığı gibi zor olmadığını söyleyerek birkaç basit tarif sıralar. İlyas bağırmaya devam eder. Yazar, bu tuhaf kavgada okuyucuya kendi gibi kavganın şahidi olan Murat'ın şaşkınlığıyla özdeşleşme imkânı sunar:

\footnotetext{
“Adam işi pişkinliğe vurmak istedi. Yüzündeki gülümseme yanıp yanıp sönüyordu, tümden silinmemesi için adam büyük çabalar harciyordu. Korkunç bir gülümsemeydi. Omuz silkti.

“Ucuza mal olur,” diye ekledi. Sonra Murat'a göz kırptı. Şimdi terlemeye başlamıştı. İri iri damlalar vardı alnında. Gene konuştu. "Ama bulaşık yıkamak sıkıcı," dedi.

"Sus!" diye bağırdı İlyas. "Sus dedim sana!"

Ama adam şaşkınlıktan donakalmış Murat’a bakıyordu.” (Yücel 2016: 26)
}

İlyas adamın "korkunç" gülüşüne, terleyen yüzüne daha fazla tahammül edemez; bir anda yakasına yapışır. Ancak adam kendinden beklenmeyen bir 
çeviklikle İlyas'ın elinden yakasını kurtarır ve yüzüne bir tokat atar. Derken, hızla kapıya koşarak çıkıp gider. Bu sahnenin sonunda Murat, babasının arkadaşı olan ve elinde büyüdüğü yaşlı adama neden böyle davrandığını sorunca İlyas, geleneksel okurun alışkın olduğu neden-sonuç ilişkisini bütün bu sahneyle uyumlu biçimde son bir kez daha tepetaklak edecek bir cevap verir: "Kötü gülüyordu," diye söylenir İlyas, "Eşek gibi, öküz gibi gülüyordu, dayanamadım...” Murat’ın "Ya delisin ya şairsin sen" dediği İlyas, aynı sinir buhranı içinde kararını açıklar: "Bundan böyle ben de yemek yapacağım!" (Yücel 2016: 27). Murat, son zamanlarda bir hayli zayıflamış gördüğ̈ İlyas'a Emel'i düşünmekten alıkoyacağını umarak bu kararında destek olur. Parasızlık çektiğini bildiği dostuna maddi destek olmak için mutfağındaki eşyalardan dilediğini seçmesini söyler. Böylece, İlyas profesyonel bir aşçının çalışma alanına dönüştüreceği mutfağının ilk araç gereçlerini edinmiş olur. Bunlar, onun bir tutku haline getireceği yemek yapma işinin ilk arzu nesneleridir aynı zamanda:

“Tencereyi, tabakları, kaşıkları küçük, tozlu mutfağına yerleştirdi. Soğuktu, çok üşüyordu. Yorgundu da üstelik, hemen yatması gerekirdi. Gene de ayrılamıordu mutfaktan. Gözlerini ayırmadan tencereye, tabaklara bakıyordu. Çok güzel bir resme bakar gibi. Tencere tencere değildi sanki, tabaklar tabak değildi, ölümsüz ellerden çıkmış ölüm kalım eserleriydi. Belirsiz bir hazla, bulanık bir öç duygusuyla bakıyordu. Bir yabancı, bir sonsuz hüzün, bir tuhaf dinginlik veriyorlardı. Ama Divitoğlu sanki büyülenmişti, bakmaya doyamıyordu." (Yücel 2016: 28).

Mutfak eşyalarının “açık dost, her zaman için güvenilir çehreleri” İlyas'a Tanpınar'ın öykü karakteri Abdullah Efendi'nin eşyalara beslediği cinsten bir aşinalık ve aidiyet duygusu hissettirirler (Tanpınar 2013: 20). Mutfak, içindeki yeni eşyalarla 'ev'in merkezidir artık. Sicaklık ve güven duygusu veren bütün eşyasıyla İlyas’’ adeta “ilk evreni”ne döndürmüştür:

"Ev insan yaşamında, kazanılmış şeylerin korunmasını sağlar, bunları sürekli kılar. Ev olmasaydı, insan dağılıp giderdi. Ev, insanı gökten inen firtınalara karşı olduğu gibi, yaşamında yaşadığı firtınalara karşı da ayakta tutar. Aynı zamanda hem beden, hem ruhtur. İnsan varlı̆̆ının ilk evrenidir.” (Bachelard 1996: 34-35)

İlyas'ın mutfağı bu haliyle kitabın adının vadettiği üzere bir “çıkmaz” olmaktan çok uzaktır. Genç adam, ertesi gün de ilk iş mutfağa girer, yeni eşyalarına bakar ve gittikçe ustalaşacağı yemek yapmada kendisine yardımcı olan araç 
gereçlere bütün parasını harcar. Murat, yemek yapmaya iki üç parça kap kacakla başlayan İlyas'ın mutfağını aylar sonra tekrar gördüğünde şaşkınlığını gizleyemez: "Öyle ya, şimdi maltızdan kepçeye, kepçeden havana, eleğe kadar her şey vardı bu mutfakta! Çok güzel, çok düzenli, çok temiz bir mutfaktı, her şey yerli yerinde, her şeyi tamamdı" (Yücel 2016: 110). Murat İlyas'a verdiklerini geri almak üzere girdiği mutfaktan hiçbir şey eksilmeyeceğini anlayarak çıkmak zorunda kalır. Kapsız kacaksız kalacağını, yemek yapamayacağını düşündüğü İlyas'ın mutfağının onu ele geçirdiğini biraz şaşkınlık, biraz dehşetle fark eder.

Lefebvre, Mekânın Üretimi (La production de l'espace, 1974) adlı eserinde mekânın toplumsal bir ürün olarak algılanmasının yeni bir olgu olduğundan söz etmektedir (2014: 23). Toplumsal mekânı toplumsal üretim olarak değerlendiren Lefevbre'nin tanımıyla uyumlu olarak, mutfak ve yemek kültürünü toplumsal tarihle iç içe ele aldığı çalışması Mutfakta Tarih-Yemeğin Politik Serüvenleri'nde (2015) Burak Onaran, yemek yapmayı/yemeyi siyasal tarihin "mutfağında kalmış" bir parçası olarak değerlendirmektedir (2015: 9). Mutfağın bir mekân olarak evin sınıfsal özelliklerini yansıtan önemli bir alanı olarak ortaya çıkması kuşkusuz burjuva sınıfının kendi yemek zevkini arayıp yaratması ve bunun için önemli miktarda maddi kaynak ayırmasıyla mümkün olmuştur. Murat Belge yemekle ideoloji arasında ilgi kurarken ulusal mutfağın "bir dünya görüşünün ürünü” olduğunu kaydetmektedir (2016: 15). Ancak, şimdiye kadar verilen örneklerde siyasal ve sınıfsal okumalara imkân veren mutfağın Mutfak Çıkmazı'nda toplumsal değil, varoluşçuluğun değerlerine uygun biçimde bireysel bir alan olarak işlendiği dikkati çekmektedir.

Bunun dışında, mutfak, varoluşçu edebiyat için sokaklar, 1ssız doğa veya kalabalık şehirler kadar uygun bir mekân gibi görünmese de çeşitli potansiyelleri barındırması bakımından bireyin iç dünyasını sunmak için elverişli bir mekân seçimidir. İlk bakışta, anlamsızlık, cinsellik, intihar, sıkıntı, suç gibi genel temaları düşünüldüğünde, mutfakla bağdaştırılamayacak varoluşçu edebiyatın bütün bu temaları birleştiren sözcüklerden birinin "bulantı" olması önemlidir. Sartre'ın iddiasının aksine iyimser ve hümanist özelliklerinden çok karamsar/sinik tarafıyla öne çıkan varoluşçu felsefenin bedensel alandan devşirdiği zihinsel bir süreci ifade etmek için, yine Sartre'ın romanına isim olarak seçtiği, "bulantı”, bu felsefenin 
en önemli kavramlarından biri olan yabancılaşmanın da edebî ifadesidir. Ancak sözcüğün ilk çağrışımı, kuşkusuz, zihinsel değil, bedenseldir. Örneklerine 1950 kuşağı öykücüleri arasında da bolca rastlanabilecek varoluşçu edebiyatın mutfakla ilişkisinin son derece zayıf olduğunu ve genel anlamda 'mide bulantısı' yla açıklanabileceğini belirtmek gerekir. Roman ve öykü karakterlerinin büyük kısmının günlerce aç kaldıkları, önlerine gelen yemeğe dokunamadıkları ya da beğenmedikleri, yer yer öğüre öğüre kustukları görülür (Dirlikyapan 2013: 111154). Bu anlamda, varoluşçu edebiyatın yemek söz konusu olduğunda 'bulimik' bir tutum içinde olduğunu kaydetmek gerekir.

Açık biçimde varoluşçu olmadığı halde bu felsefeye ait kavram ve düşünceleri edebiyata en güçlü şekilde aktaran Kafka'nın "Bir Açlık Şampiyonu" adlı öyküsünde, bir sirkte çalışan ve aylarca yemek yemeden hayatta kalabilen kumpanya elemanı, yemek yememesinin nedenini soran bir yetkiliye, "Çünkü hoşuma giden yemek bulamıyorum. Bulsam inanın ki böyle bir ün peşinde koşmaz, ben de sizin gibi, başkaları gibi karnımı tıka basa doldururdum" cevabını verir (Kafka, 2016, 242). Kafka, Gregor Samsa'nın başta kendine ve içinde yaşadığı topluma yabancılaşmasını çarpıcı bir başkalaşım metaforuyla anlattı̆̆ı Dönüşüm romanında, başkarakterin okuyucu üzerinde yarattı̆ğ etkiye benzer tiksindirici bir yemek yeme sahnesi kurar:

"Durmuş ve yarı çürümüş sebzeler; akşam yemeğinden kalma, üstünde donmuş beyaz sos bulunan kemikler; birkaç kuruüzüm tanesi ve badem; Gregor'un iki gün önce bu yenmez dediği bir peynir, bir dilim tereyağlı ekmek ve bir dilim tereyağlı, üstüne tuz ekilmiş ekmek. Kız kardeşi bunlarla birlikte içi su dolu bir kap da getirmişti ve kap herhalde bundan böyle yalnız bu iş için kullanılacaktı. (...) Peyniri, sebzeleri ve sosu birbiri ardına ve mutluluk gözyaşları arasında midesine indirdi; buna karşıllk taze yiyeceklerden hoşlanmamıştı, dahası, bunların kokusuna bile dayanamıyordu ve asıl yemek istediklerini biraz öteye taşıdı.” (2015: 43-44)

Kız kardeşinin Gregor Samsa'ya yemesi için getirdiği yiyecekler, evde kiracı olarak kalan beyefendilerden kalan artıklardır. Çöpe gitmesi gerekirken Gregor Samsa'nın önüne gelen bu artıklar, onun dönüşümünü yansıtması bakımından önemlidir. Samsa, hiç iğrenmeden yer kız kardeşinin getirdiklerini; hatta "iki gün önce yenilemeyecek kadar kötü” bulduğu peynirleri “memnuniyetten gözleri yaşararak” yer. Bir tek taze yiyeceklerden hoşlanmaz. Onları bırakır. Bu okuyucuya 
“bulantı” veren sofra, Gregor Samsa'nın tam anlamıyla böcekleştiğinin delilidir.

Bir diğer örnekte, Sartre, Bulantı (La Nausée, 1938) romanında, deniz ürünleriyle zihnin kıvrımlarında gezinen düşünceler arasında kurduğu ilişkiyle "bulantı" sözcüğünü romana isim olarak seçmesindeki estetik kaygıyı net biçimde yansıtır. Romanın anlatıcısı Antoine Roquentin, kendisi sekiz yaşındayken Lüksemburg parkındaki bekçi kulübesinde saatlerce oturarak birinde potin birinde terlik olan ayaklarını izleyen ve sonradan dengesiz hareketleri yüzünden işinden atıldığını öğrendiği malulen emekli müfettişten pakta oynayan çocukların duyduğu tedirginliği şu sözlerle anlatır: "Bizi korkutan yalnızlığıydı. Kafasında çağanoza, 1stakoza benzeyen korkunç düşünceler kurduğunu sanıyorduk" (Sartre 1995: 22-23). Burada, deniz ürünlerinin yapış yapış, akışkan, sümüksü dokusuyla kafanın içindekiyle, yani beyinle kurulmuş başarılı bir benzeşim de söz konusudur. $\mathrm{Bu}$ zihinde kıvrılan, dolanan, sarmalanan düşüncelerin sağlıklı veya huzur verici olmasinın yolu yoktur.

\section{Yemek Yapmanın ve Yemenin Felsefesi}

Mutfak Çıkmazı'nın felsefi altyapısını daha iyi ortaya koymak adına varoluşçuluğun tarihine kısaca baktığımızda, oldukça farklı felsefe ekollerinden faydalanan eklektik bir yapıyla karşılaşmaktayız. Marx'ın diyalektik materyalizm düşüncesini borçlu olduğu Hegel'in usçu ve diyalektik görüşlerine karşı Bergson, Blondel, Brunschving gibi düşünürler Kierkegaard, Nietzsche ve Scheler' in attığ ilk tohumları geliştirmişlerdir (Bozkurt 2008: 111-152). İki dünya savaşı arası dönemde Nazi yanlısı Heidegger'in eserleri Avrupa'da büyük yankılar uyand1rırken II. Dünya Savaşı'nın devam ettiği yıllarda Sartre, savaşın yol açtığı büyük yıkımı felsefesinin "insancıl" ve "umutlu" yanının malzemesine dönüştürmeyi başararak varoluşçuluğu bütün dünya kamuoyunun tartıştığı bir konu haline getirmiştir. Daha önce dile getirildiği gibi, Türkiye'nin varoluşçu felsefeyle ilk kez temasa geçtiği yıllarda, başta Frankfurt Okulu aydınları olmak üzere, Kuzey Amerika ve Avrupa entelijansiyası, II. Dünya Savaşı'nda sayısı on milyonu aşan kitlesel ölümlerde, yakılıp yıkılan şehirlerde insan kötülüğünün payını, insan olmanın sorumluluklarını ve mutlak adalet arayışını geniş oranda tartışmaktaydı (Arendt 2016: 260). Savaşın yarattığı ağır maddi ve manevi tahribat, insan sorumluluğuna 
yaptığ1 vurguyla varoluş̧̧u felsefeyi Avrupa'dan başlayarak bütün dünyanın gündemine yerleştirmişti. Sartre'ın "varoluş”un “öz"den önce geldiği görüşü, insanı bütün yaptıklarından sorumlu tutmakta, belli bir türe dâhil her varlığın o türe ait niteliklere ya da özelliklere sahip olduğunu savunan Özcülük'ün tersine, kendi seçimleriyle varlığına bir öz kazandırdığını iddia etmekteydi. Sartre, "Varoluş̧̧uluk Bir Hümanizmdir" başlıklı konferansında varoluşçuluğu, savaş sonrası hızla yayılan özgürlükçü ve hümanist rüzgârı arkasına almasını sağlayacak biçimde ve en yalın bir ifadeyle, "Ilkin insan vardır; insan önce dünyaya gelir, var olur, ondan sonra tanımlanıp belirlenir, özünü ortaya çıkarır” (Sartre 2010: 39) şeklinde tanımlamaktaydı.

Önceki bölümde anlatıldığı üzere, İlyas'ın kendi yemeklerini yapmaya başlaması, ekonomik nedenlerle alınmış bir karar gibi görünmektedir. Murat'ın ofisindeki adsız misafirin anlattıklarının etkisiyle yemek yapmaya karar vermesini Murat da ilk başta ekonomik ve moral nedenlerle destekler. İlyas'ın yemek yapmaya başlaması, aynı zamanda, Divitoğlu ailesinin çöküşünün bir delilidir. Yapacağı ilk yemeğe koymak üzere kasap dükkânına giren İlyas, sıra kendisine gelene kadar büyük bir utanç içinde kıvranır. "Divitoğlu kasap dükkânında ne yapiyormuş, derler. Memlekete rezil oluyorum," der kendi kendine (Yücel 2016: 29). Memleketindeki akrabaları ve onların ataları "yoksul düşüp uşaksız kalınca" alın teriyle para kazanmayı düşünmek bir yana çarşıya inmeyi, esnafla pazarlık etmeyi, eve öteberi taşımayı bile küçüklük sayacak kadar kibirli ve eşraf ruhlu insanlardır. Geçmiş günlerin geri geleceği hayaliyle bütün umutlarını İlyas'a bağlarlar. "İlyas onların torunuydu. Bu nedenle yüzü sapsarıydı, alışveriş etmiyor da bir şey çalıyordu sanki." Kasaptan aceleyle dışarı kaçar. "Sanki tüm gözler üzerindeydi, sanki herkes biliyordu bu eti kendi eliyle pişireceğini. Sanki herkes için için alay ediyordu!” (Yücel 2016: 30). Akrabalarının İlyas'a bakış ve ondan beklentileri, onun arkadaş çevresinde de egemendir. Örneğin, onun yaptığ1 yemeklerin kısa sürede müdavimi haline gelen Selâmi, İlyas'tan gelen yemek davetini ilk başta ciddiye almaz ve onun yemek yaptığına ihtimal dâhi vermez: "Divitoğlu zengin değildi, aşçı maşçı tutamazdı, aşçı tutabilecek durumda olsa, bu evde oturmazdı, kadınlarla da ilgilenmezdi, öte yanda hem soylu, hem gururluydu, eliyle yemek yapmazdı." (Yücel 2016: 52). İlyas'1 yemek yapmaktan 
vazgeçirmek için uzun uğraşlar veren Murat da Selâmi’yle aynı düşüncededir. İlk başta desteklediği halde ona yemek yapmayı yakıştıramaz: "Yemek yapacak adam mısın sen? Koca İlyas Divitoğlu yemek yapar mı? Yapmaz! Şu ellere bir baksana: tutsa tutsa divit tutar, kâğıt tutar bu eller. Kap yıkamak, salata yapmak, soğan doğramak yakışmaz bu ellere" (Yücel 2016: 60).

İlyas'ın tutku haline getirdiği yemek yapma alışkanlığına itirazlar benzer argümanlara dayalıdır. Oysa roman boyunca okuyucuya sosyo-ekonomik nedenlerle bir arada düşündürülen yemek yapmak, ekonomik zorunluluklardan çok ontolojik tercihlere dayanmaktadır. Yemek yapmaya başlamadan önce memleketten gelen paralarla dışarıdan yiyerek hayatını idame eden İlyas'ın bir anda mutfağa kapanmasını, bu bakımdan parasal nedenlere bağlamak doğru değildir. Parasal durumu, İlyas'1n tutkusunun görünen kısmıdır sadece. Emel'in, onun evlilik teklifini reddetmesiyle başlayan psikolojik çöküşüne karşı geliştirdiği savunma mekanizmasının kılıfıdır. İlyas, memleketteki akrabalarından para istediği mektuplarında ekonomik durumundaki kötü gidişi iyi bir bahane olarak kullanır:

"Bu durumda geçinmeme olanak kalmadı, baktım ki olacak gibi değil: birkaç kuruş daha alabilmek için bir iş aradım, ama iş aslan ağzında, bulamadım. Yalnız küçük bir lokantadan bir aşçılık önerisi aldım, bu da işime gelmedi, geri çevirdim, amcacığım. Aç da kalsam, çıplak da kalsam, dedelerimin kemiklerini sızlatamazdım. İşte böyle, amcacığım, durumum kötü, olanak varsa, bundan sonra aylığımı biraz artırın.” (Yücel 2016: 89)

İlyas mektubunda ne yeni saplantısı yemek yapmaktan ne de bu yemekleri daha iyi ve çeşitli yapmasını sağlayacak yeşil kitaplara sahip olmak için duyduğu şiddetli arzudan söz eder. Aksine, inkâr yoluna gider. Aşçı olarak çalışabilecekken bunu kesinlikle geri çevirdiğini anlatır. İlyas, bütün obsesifler gibi, saplantısını hiçbir şekilde açık etmemesi gerektiğinin bilincindedir. Günlük hayatında yalnızca yemeklerden bahsetse de başka mecralarda bunun tehlikesinin farkındadır. Dil sürçmeleri dâhil olmak üzere, her hareketine özen gösterir. Ancak tümüyle kontrollü davrandığını söylemek de mümkün değildir. Örneğin, mektubunun devam eden satırlarında yaptığı bir benzetme, onu ele verecek türdendir: "Paralara bir hal oldu, kötü yağlar gibi buhar oluyorlar, yerlerinde bir şey kalmıyor” (Yücel 2016: 89). 
İlyas, hayatını tümden değiştiren yemek yapma tutkusunun yönlendirmesiyle okulunu bırakır, mutfağa kapanır. Bütün insanlardan kaçarak orada yaşamaya başlar. Görüştüğü birkaç kişiyle de yalnızca yemekler üzerinden iletişim kurar; ya yemekler hakkında konuşur ya da onlara yaptığı yemeklerden yedirir: "Yemekleri yaparken de, yerken de bir mutluluk duyuyordu. Ya yemek yapıyor ya yemek yiyor ya yemek düşünüyor ya uyuyordu. Bu nedenle sürekliydi mutluluğu” (Yücel 2016: 48). İlyas'ın mutluluğunun varoluşçu felsefede geçerli bir nedeni vardır. Varoluş̧uluğun "İnsan kendi kendini seçer" ve "İnsan sorumludur" (Sartre 2010: 41) ilkelerine uygun olarak aldığı kararın sorumluluğunu üstlenir. Yaptığı tercihle, başkalarının onun önüne koyduğu seçenekleri reddetmiş olur. Akrabaları ondan hukuk fakültesini bitirip büyük dedesi gibi yargıtay üyesi olmasını beklerler. Ancak o, yapmak istediği işi yaparak mutlu olmayı seçer. İlyas yemek yaptığı ve bu yemekleri yediği anlarda gerçekten mutlu olur. Bir hayli acemilik çektiği ilk yemeğinde bile bu böyledir: "Engin, yumuşak, serin, uzak bir haz titreşimiydi. Düş gibi, çocukluk gibi, memleket gibi, ev gibi bir titreşimdi. Önce ağzına yayılıyordu, sonra tüm varlığına” (Yücel 2016: 32). Yücel, İlyas'ın yemek yapmaktan aldığı zevki sanatsal hazla denk tutar: "Divitoğlu artık coşmuş, yeryüzünden uzaklaşmış bir sanatçıydı, yaşayışı, varı yoğu sanat olmuş bir sanatçı gibiydi. Durmadan yaratıyordu. Yarattıklarına hayrandı. Ama yeteneği konusunda kuşkuya düştüğü de olmuyor değildi." İlyas üretimini başkalarıla paylaşmak isteyen bir sanatçı gibi hisseder: "Başkaları ne derlerdi yemeğini yiyince, neler duyarlardı, bunu bilmek istiyordu." (Yücel 2016: 52) Selami’ye göre de, "Bu yemek değil, bir şiir(dir)..." (Yücel 2016: 57). İlyas, daha ileri giderek, bir davette karşılaştığı bir kadına yemek tutkusundan bahsederken yemek yapmanın bedenle ve ruhla yapılan bir sanat ve bir Tanrı vergisi olduğunu söyler. Ona göre herkesin yapamayacağı bir yetenek olan yemek yapmak “Aşk gibi” yücedir (Yücel 2016: 71-72).

Yemek yapmak İlyas'a kendi hayattaki amacını vermiş gibidir. Ancak bu yolda zaman zaman dalgalanmalar yaşadığı da vâkidir. Örneğin, memleketten ziyaret için gelen bir akrabasını evden savdıktan sonra İlyas kısa süreli bir pişmanlik bile yaşar: "Ben böyle olacak adam değildim," Gerçekten Yargitay üyesi olabilirdim," diyerek hayatına kahreder (Yücel 2016: 103). Ancak uyuyup uyandıktan ve tekrar acıkıp karnını kendi elleriyle yaptığı lezzetli yemeklerle doyurduktan sonra bütün pişmanlığını unutuverir. Tekrar mutfağa kapanır. 
İlyas, yemek yaparak başkalarının değil, kendisinin olmak istediği insan olmuştur; tam anlamıyla dönüşmüştür. $\mathrm{O}$ artık bambaşka biridir. Yaptığı yemeklerde ve özellikle Batı mutfağında kendini bulmaktadır (Yücel 2016: 125-126). Yaptığı yemekler, gerek kurmaca gerek gerçek dünyadaki mutfakların ve yemek sofralarının egemen duygusuna uygun olarak, ona kendini tanıma, başkalarıyla paylaşma firsatı verdiği için Mutfak Çıkmazı'nın aşçısı son derece mutludur. Ancak kendini "istediklerini kesinlikle gerçekleştirmeyi başarmış, rastlantıların ya da alınyazısının çizdiğini değil de, kendisi için uygun bulduğu yolu izleyen bir adam" (Baran 1975: 8) olarak tanımlayan ve kısa sürede hayatının bütün kontrolünü kaybeden Bir Solgun Adam romanının başkarakteri emekli bankacı Mehmet Taşçı gibi, İlyas Divitoğlu da psikolojik olarak parçalanmaya yazgılıdır. Kişisel bir karar olarak onu düze çıkaran yemek yapmak, bu kısa romanın kurgusunun el verdiğince kısa bir süre içinde, İlyas'ın ruhunu ele geçiren bir tutkuya dönüşecek ve onu insanlardan uzaklaş̧ırarak bütün hayata yabancılaştıracaktır.

Yabancılaşma, nesnelerin bilinç için yabanc1, uzak ve ilgisiz görünmesi; daha önceden ilgi duyulan şeylere, dostluk ilişkisi içinde bulunulan insanlara karş1 kayıtsız kalma, ilgi duymama, hatta bıkkınlık ya da tiksinti duymadır (Cevizci 2002: 1099). Yabancılaşmanın varoluşçu filozofların hareket noktası olduğunu dile getiren Akdeniz'in P. Tillich’ten aktardığına göre, varoluşçuluk "insanın sanayileşmiş toplum içinde insanlıktan çıkarılmasına karşı yürütülmüş yüzyıllık bir başkaldırıdır" (2012: 17). Eserlerinde genellikle topluma ve kendi özlerine yabancılaşmış karakterlere yer veren varoluşçu yazarlar, kayıtsızlık veya şiddetli tutkuların bir sonucu olarak toplumla sağlıklı ilişkiler kurma becerisini yitirmiş kişilerin hikâyelerine yer verirler. İlyas, kontrolden çıkan yemek yapma hırsıyla kısa sürede yaptı̆ğ işin kendisine de yabancılaşır. "Yabancılaşmada insan, tutkuları ve yerleşik alışkanlıkları nedeniyle; kendisine, ilişkilerine ve eylemlerine yabanc1 hale gelir" (Akdeniz 2012: 13-14) tespitine uygun olarak, yemek kitaplarına bakmadan yemek yapan, işinde yalnızca sezgilerine güvenecek kadar ustalaşan İlyas yaptığı bütün yemeklerden kısa sürede sıkılır. Bunun için iyi bir gerekçesi de vardır: bir yemek davetinde adını ilk defa duyduğu Fransız yemeği coq-au-vin.

"Bu yemeğin varlığını öğrendiği günden beri huzursuzdu, merak içindeydi. Yemekler ilk tatlarındaydı, daha da tatlıydı belki, ama ilk tatlarını vermez olmuşlardı artık, ko- 
lay ve sıradan görünüyorlardı İlyas'a. Oysa İlyas'ın içinde, hiç durmadan ilerlemek, durmadan kendini aşmak isteyen bir sanatçı kaygısı vardı, daha yeni, daha başka, daha ender yemekler yapmak isterdi, yaratmak isterdi! S1kılıyordu bu yüzden, ölümüne sık1lıyordu." (...) "Şaraplı horoz!.. Ya da şarapta horoz, ikisinden biri işte... (...) Çözülmez bir denklemdi gâvur yemeği!” (Yücel 2016: 83, 90)

İlyas yeni amacına ulaşmak için girdiği uzun uğraşların ardından bir sahhafta, içinde coq-au-vin tarifinin de bulunduğu bir yemek kitabı seti bulur. Bu "yeşil kitaplar" onun yeni mutsuzluk nedeni olur. İlyas yemekler yapmaya devam eder. "Ama yemekleri yapmaktan da, yemekten de eski tadı alamıyordu(r)" (Yücel 2016: 97). İlyas bütün parasını bu kitapları satın almak için harcar ve yeni yemeğini ve diğer bilinmedik tarifleri zevkten kıvranarak yapar. Kısa sürede, bu kitaplardaki bütün yemekleri de yapabilir hale gelir. Onun çöküşünü önlemek için evlilik teklifini geç de olsa kabul ettiğini söyleyen Emel'e verdiği cevap, yemek yapma tutkusunun onu tümüyle ele geçirdiğini gösterir. İlyas, Emel'in teklifini ona duyduğu öfkeyle değil, yemek yapma tutkusuyla reddeder: "Kadınları bilirim ben: mutfaktan çıkmak bilmezler." (Yücel 2016: 120). Aşka ve evliliğe kapılarını kapatan İlyas, fakülteden hocası Orhan Bey'in ikna çabalarını da boşa çıkararak kariyerini de mahveder. Yalnızlık, parasızlık, mutsuzluk ve tatminsizlik bir araya gelerek onu kısa sürede yatağa düşüren hastalığa neden olur. İlyas'ın mutfağı, kitabın adının da vadettiği üzere, hem bedeninin hem ruhunun acıdan kıvrandığı bir çıkmazdır artık.

Bu noktada, İlyas'ın bir roman karakteri olarak psikolojik gelişimi ve kişisel tutarlılığında varoluş̧̧u felsefe açısından bazı sorunların ortaya çıktığı gözlemlenmektedir. İlyas'ı eğitimini yarıda bırakıp yemek yapmaya götüren kararı onun öznelliğini ve bütünlüğünü koruması açısından anlamlı ve değerlidir. Yemek yapmak, ilk başta, Emel'in evlilik teklifini reddiyle başlayan kriz karşısında parçalanışını önler, ilerleyen aşamalarda en büyük mutluluk kaynağı olur. Ancak bu oldukça kısa sayılabilecek romanın yoğun olay örgüsünde İlyas için durum az zamanda tersine döner. En büyük tutkusu ve mutluluğu, kişisel kriz kaynağına dönüşür. Yemek yapma hırsı onu gerçeklikten koparır. Bunun nedeni, romanın olay örgüsü içinde yeterli ve güçlü bir entrika unsuruyla verilmiş olmamasına rağmen, İlyas'ı en başta kişisel bunalıma sürükleyen Emel'le mutlak biçimde yollarının ayrılmasıdır. İlyas'ı içine sürüklendiği derin uçurumdan çıarmak için ortak hareket 
eden Emel'le Murat zamanla yakınlaşırlar ve kısa zamanda evlilik kararı alırlar. İkisi, mutluluklarını yaşayacakları çiftlik evine taşınma tasarısına İlyas'ı da dâhil ederler. Böylece, İlyas'1 Adana'ya götürüp orada bir et lokantası açmak ve kendi kız kardeşiyle evlendirmek planları kuran Selami’yi saf dışı bırakarak çiftlik evlerine aşçı olarak götürürler. Normal şartlar altında, başka insanların kendi yaptığı yemekler için ne düşündüğünü önemseyen, bundan zevk alan İlyas'ın yeni yaşantısından memnun olması beklenir. Ancak Emel'i kaybetmiş olması ve parasal nedenlerle kendini Murat'a borçlu hissetmesi yeni bir krizin tetikleyicisi olur.

Varoluşsal olarak İlyas'1n yegâne mutluluk nedeni olan yemek yapmak onu insanlardan nefret ettiren en büyük neden haline gelir. Yemek yapanla yiyen arasında kolay kolay kurulması beklenemeyecek bir "köle-efendi" ilişkisi kurulur. Örneğin, Selami için şunlar söylenir: "En ince yerinden, midesinden bağlanmıştı ona. Divitoğlu'nun evinde pişen yemeklerin kokusu burnunda tütmeye başladı mı bir yerlerde duramaz oluyordu" (Yücel 2016: 104). İlyas, bir süredir tek anlamlı ve sağlıklı ilişki kurduğu canlı olan kedisi Aliye'nin kaybını insanlardan bilir: "Bütün insanlardan tiksin(ir)" (Yücel 2016: 133). Yine, Emel-Murat çiftinin onu aşçı olarak çiftliğin mutfağına kapatmaları İlyas'ın kendini bir tutsak gibi hissetmesine neden olur: "Her şey mutfaktı işte, yaşamı bu mutfaktı! Yaşamını değiştirmek de istemiyordu. Artık neye yarardı ki? Bu mutfakta ölecekti..." (Yücel 2016: 142). İlyas'ın değişim arzusu da hayatını kendi ellerine alma yetisi de tükenmiştir. O, mutfakta ölecektir. İlyas'ın kehaneti iki sayfa sonra gerçekleşir ve onu bir çiftlik aşçısı olarak karşısında bulan amcasının oğlu Mustafa tarafından öldürülür. İlyas, daha fazla değişmekten vazgeçtiği noktada, hâlihazırda akrabalarının tanıyıp bildiği İlyas Divitoğlu olmaktan fazlasıyla uzaklaşmıştır. Mustafa’nın "Divitlerden değil misin?" sorusuna, "Bir aşçı parçasıyım” diye cevap verir (Yücel 2016: 143).

Buraya gelindiğinde, romanın hem başında hem sonunda tekrarlanarak bir döngü oluşturan İlyas'ın ölümüyle ilgili satırlara odaklanmak gerekmektedir. Yücel, İlyas'1 öldürenin Mustafa değil, etrafındaki herkes olduğunu dile getirirken onu bir "toplum kurbanı" olarak gösterir:

“Ne derlerse desinler, gerçek İlyas'ı Mustafa öldürmedi. O İlyas değildi, onların İlyas'1 değildi. Mustafa'nın vurduğu bir bedendi, bir insandı, ama o İlyas değildi. O İlyas'ın 
buz gibi soğumuş cesedini taşıyordu içinde, adı İlyas'tı, ama o İlyas değildi, başka biriydi. Mustafa'yı öldürmekle alınmaz İlyas'ın öcü. İlyas'a kıyanlar başka, İlyas'a kıyanlar bir sürü, İlyas’a kıyanlar sayılmaz...” (Yücel 2016: 17).

Romanın sonunda, İlyas'ın Mustafa'ya “Divitlerden değilim” dediği ve Mustafa’nın kurşunlarının hedefi olduğu bölümde aynı düşünceler tekrarlanır:

“Gerçeği söylüyordu: Divitoğlu gerçek Divitoğlu değildi artık. O çoktan ölmüştü, öldürmüşlerdi. Görünüşü, yüzü, sesi bir aşçıda kalmıştı, ama İlyas Divitoğlu yoktu artık, çoktan ölmüştü.” (Yücel 2016: 143)

İlyas yemek yapmaya başlama kararıyla hukuk öğrenimini yarıda bırakmıştır. Mutluluğu, iyileştirici, zevk verici, paylaşımcı ve birleştirici etkileriyle yemek yapmakta bulur. Akrabalarının ondan beklentilerine sırtını çevirerek kendi mutluluk anlayışının peşinden gider. O, ailesinin, arkadaşlarının tanıdığı kişi değildir artık ve ona bir "yabancı" olarak bakan çevresi onu yok eder. Yukarıdaki alıntılarda belirtildiği gibi, onu öldüren, ikiyüzlü ahlakı ve çıkarcılığıyla bütün bir toplumdur. Başta, kendisini terk edip en yakın arkadaşı Murat'la evlenen Emel olmak üzere tanıdığı, yakınlık kurduğu herkes onu bir şekilde sömürür. Selami yemekleri için onunla arkadaşlık kurar. Murat, bir süredir hoşlandığı Emel'i elde etmek için ona yakın davranır. İlyas etrafındaki insanlardan nefret etmek için haklıdır bir bakıma. Uzun süre ilişki yaşadığı Emel, Murat'ın kendisini öpmesine izin verdiğinde, "İlk siz öpeceksiniz beni, annemden, babamdan, ciciannemden sonra ilk siz..." der (Yücel 2016: 123). Murat, Emel'le evlilik kararını İlyas'a açıkladığındaysa Murat'ın kendi yerine ödediği kiraları düşünerek susmak zorunda kalır (Yücel 2016: 137). O da susmak zorunda bırakılarak bu sömürü düzenin bir parçası haline gelir. Yeni evli çifte ait çiftlikteki mutfakta çalışmak İlyas’ı büsbütün tüketir. Bir süre rahatça çalıştığı yeni, kusursuz, güzel ve geniş mutfağında huzursuzluk eninde sonunda onu ele geçirir. Bütün sakinlerinden uzak durarak çalıştığı çiftlikte sürekli “Beni yalnız ölüm paklar” diye sayıklayarak gezinir (Yücel 2016: 141). İlyas'ın yemek yapma tutkusunu yitirerek ölmeyi seçmesinde, birbirinden lezzetli yemeklerini, kelimenin gerçek anlamıyla bir obur olan Selami yerine, mutluluklarına imrendiği Emel-Murat çifti için yapmak zorunda kalışının etkisi de unutulmamalıdır. 


\section{Mutfak Çıkmazı'ndan Çıkan Yemekler}

Gerek konusuyla gerek hikâyesiyle başından sonuna ve tam anlamıyla yemek yapmak ve yemek yemek hakkında bir roman olma özelliği taşıyan Mutfak Çıkmazı'nda adı geçen yemek çeşitlerinin bu başlık altında ele alınmasının faydalı olacağı kanaatindeyiz. Mutfak Çıkmazı'nda yemek yapmaya yüklenen felsefi anlamın dışında, yiyecekler hakkındaki bütün eserlerde olduğu gibi burada seçilen yemeklerin de bir simgesel değeri olduğunu düşünmek için çeşitli ipuçları bulmak mümkündür. Örneğin, İlyas’1 yemek yapmaya teşvik eden karşılaşma anındaki yaşlı adamın anlattığı tariflerin hepsi sahanda yumurta, patates haşlama gibi ekonomik malzemeler ve pratik yöntemlerle yapılan yemeklerdir. İlyas'ın ilk yemeği de bu tariflerden biri olur zaten. Ancak İlyas yemek yapmak konusunda uzmanlaştıkça tariflerin malzeme çeşitliliği ve uygulama zorluğu da artar. İlyas'ın bu aşamada yerli yemeklerden "pastırmalı yumurta, kuru fasulye" (Yücel 2016: 43) "düğün yahnisi, kaytan kebabı, yoğurtlu kebap, Hacı Osman kebabı, lüle kebabı, püryan kebabı, böğrülce, patlıcan musakkası, patlıcan oturtması, düğün çorbası" (47) "kadınbudu köfte, 1spanak, sütlaç" (52) taskebabı (56) ve Yücel'in memleketine ait bir yemek olan "Elbistan kebabı"nı (77) dener. Yerli mutfağın onu daha fazla tatmin etmemesine neden olan coq-au-vin tarifinin peşindeki uzun arayışının ardından İlyas yönünü Avrupa mutfağına, özellikle de Fransız yemeklerine çevirir. Ancak İlyas'ın kurduğu sofraların baş konuğu Selami'nin damak zevki yabanc1 yemeklere uyum sağlayamaz. İlyas'in Loup des roches au feu de joie ve Baron d'agneau poellé' den oluşan mönüsünü duyunca itirazını şu sözlerle dile getirir:

"Ben fazla sevmedim bu gâvur yemeklerini. Avrupa'da bile yememiştim, burada yemeye başladım, ama öbür yemeklerin başkaydı. Son günlerde işi bozdun, iyiden iyiye bozdun: gelsin gâvur yemekleri, gitsin gâvur yemekleri... Başka bir şey yaptığın yok. Nerede bizim ata yemeklerimiz, nerede bunlar!” (Yücel 2016: 125)

İlyas, Selami'nin bu konuşmanın sonunda, "Bu gâvur yemeklerinde ne buluyorsun?" sorusuna: "Neyi bulacağım? Kendimi..." diye cevap verir (Yücel 2016: 126). Yücel'in iki karakter arasındaki yemek zevkleri farkl1lığı üzerinden Doğu-Batı çatışması yaratmaya çalıştığı ortadadır. Ancak bu temanın ne romanın genel örgüsüne/bütünlüğüne ne de düşünsel boyutuna herhangi bir katkı yaptı̆̆1- 
nı söylemek mümkündür. İlyas yerli mutfağı bırakıp Avrupa mutfağına geçtiği, başka bir deyişle, simgesel düzlemde kendi kültürüne sırt çevirip Batılılaştığı için mi varoluşsal bir krizin içine itilmiştir veya Batı felsefesinin bir ürünü olan Varoluşçuluk mu İlyas'ın çöküşüne yol açmıştır? Roman bu kritik konularla ilgili yeterli düşünsel/altyapısal zenginliğe sahip olmadığı için bu soruları bir mesele olarak önümüze koymak bizi hem edebî hem felsefî bakımdan bir açmaza sürükleyecektir. Sonuç olarak, romanın Batılılaşma/modernleşme eleştirisi olarak yoruma açık bir ana hikâyesi olmadığı gibi düşünsel altyapısıyla bu yan tema arasında bir bağ kurmanın da yolu yoktur. Ulusal kimlik ve yemek arasındaki ilişkinin (Ichijo-Ranta 2018) bu romanın mihverlerinden biri olduğunu söylemek zordur. Ancak, daha önce dile getirildiği gibi, bu durum, orijinal kısa öykünün daha bütünlüklü ve ayrıntılı roman türü içine yerleştirilmeye çalışırken ortaya çıkan kurgusal dağınıklık örneklerinden yalnızca biridir.

\section{Sonuç}

Bir öykü kurgusu içinde anlamlı olabilecek orijinal hikâyenin roman kurgusuna uyarlanmasıyla ortaya çıkan arızaları ve bir ilk romanın edebî/estetik kusurlarını barındırmasıyla Mutfak Çıkmazı Türk edebiyatında yemek konusunda yazılmış önemli romanlardan biridir. Mutfağın sembolik bir mekân olarak başkarakterin ruhsal çıkmazına dönüştüğü romanda tutkuları ve etrafindaki insanlarla kurduğu sömürüye dayalı ilişkileri nedeniyle bireyin kendisine, ilişkilerine ve yemek yapma eylemine yabancı hale gelişi anlatılmıştır. Dünya ve Türk edebiyatlarında çoğu zaman bedensel ve ruhsal tatmin, paylaşım ve empati gibi olumlu çağrışımlarla kullanılarak edebiyata canlılık ve insanî bir nitelik kazandıran yemek yapmak ve yemek yemek temaları, yazıldığı dönemin baskın felsefî akımı olan varoluşçuluğun etkisiyle Tahsin Yücel tarafından alışılmışın dışına çıkılarak ters yüz edilmiştir. Edebî alışkanlıklara uygun olarak, romanın ilk bölümlerinde bireysel bazda iyileştirici ve tatmin edici, toplumsal bazda paylaşımcı ve birleştirici etkileri vurgulanan yemek yapmanın git gide bir tutkuya dönüşerek başkarakter İlyas Divitoğlu'nu insanî değerlere ve hayata yabancılaştırdığı tespit edilmiştir.

Bu anlamda, yemek yapmanın Mutfak Çıkmazı'nda ikili düzeyde ele alındığ 1 görülmektedir. Kişisel bir karar olarak yemek yapmak, ilkin, varoluşçu fel- 
sefenin öznellik ve hümanizm vurgularına uygun biçimde romanın başkarakterini kendisiyle ve yemeklerini yedirdiği insanlarla uzlaştırıcı bir rol üstlenmiştir. Ancak yemek yapmak ve yemek yemek eylemleri bir saplantı haline geldikçe başkarakterin yine kendisine ve etrafindakilere yabancılaştı̆̆ gözlemlenmiştir. Başkarakteri, en başta kendisiyle ve başkalarıyla uzlaştıran eylemin sonradan yabancılaştırıcı bir eyleme dönüşmesi varoluşçu felsefenin ilkeleriyle çelişmektedir. Yine, yapılan yemeklerin Doğu-Batı çatışması düzlemine yerleştirilmeye çalışılması sonucu, bu karşıtlığın söz konusu zıt düzeylere eklemlenmesiyle romanın düşünsel altyapısını zedeleyen bir anlam ve kavram karmaşası baş göstermektedir.

Bir cümleyle özetlenmek istenirse, denebilir ki, Türkiye'de varoluşçu felsefenin kavramlarıyla yeni yeni tanışıldığ bir dönemde kaleme alınan bir ilk roman olarak Mutfak Çıkmazı, örnek aldığ Dönüşüm, Bulantı ve Yabancı adlı romanlar gibi felsefi değerinden çok, yoğun biçimde yer verdiği yemek yapmak ve yemek yemek temalarıyla Türk edebiyatında kayda değer bir eserdir. 


\section{Kaynakça}

Arendt, Hannah (2016), Kötülü̆̆̈̈n Siradanlığl: Adolf Eichmann Kudüs'te, çev. Özge Çelik, İstanbul: Metis Yayınları, 4. bs.

Bachelard, Gaston (1996), Mekânın Poetikası, çev. Aykut Derman, İstanbul: Kesit Yayıncılık.

Baran, Selçuk (1975), Bir Solgun Adam, İstanbul: Milliyet Yayınları, 1. bs.

Beardsworth, Alan ve Keil, Teresa (2011) Yemek Sosyolojisi: Yemek ve Toplum Çalışmasına Bir Davet, çev. Abdülbaki Dede, İstanbul: Phoneix Yayınları.

Belge, Murat (2016), Tarih Boyunca Yemek Kültürü, İstanbul: İletişim Yayınları, 14. bs.

Binbirçiçek Akdeniz, Emel (2012), J. P. Sartre'da Yabancılaşma Fenomeni, İstanbul: Karakoyun Yayınları, 1. bs.

Bora, Aksu, (2009), “Rüyası Ömrümüzün Çünkü Eşyaya Siner”, Cins Cins Mekân, der. Ayten Alkan, İstanbul: Varlık Yayınları, 1. bs.

Bozkurt, Nejat (2008), 20. Yüzyıl Düşünce Akımları-Yorumlar Eleştiriler, İstanbul: Morpa Kültür Yayınları, 3. bs.

Gürsoy, Deniz (2013), Yiyelim Iç̧elim, Tarihini Bilelim-Dünden Bugüne Gastronomi, İstanbul: Oğlan Yayınları, 1. bs.

Ichijo, Atsuko ve Ranta, Ronald (2018), Yemek ve Ulusal Kimlik: Gündelik Yaşamdan Küresel Siyasete, çev. Emrullah Ataseven, İstanbul: Ayrıntı Yayınları, 1. bs.

İleri, Selim (2010), Oburcuk Mutfakta, İstanbul: Everest Yayınları, 2. bs.

Kafka, Franz (2015), Dönüşüm, çev. Ahmet Cemal, İstanbul: Can Yayınları, 48. bs.

Kafka, Franz (2016), Bütün Öyküler, çev. Kâmuran Şipal, İstanbul: Cem Yayınevi, 5. bs.

Kırkoğlu, Serdar Rıfat (2004), "Yeme-İçme ve Edebiyat", Kitaplık Dergisi, S.78, Aralık, s. 87-88.

Onaran, Burak (2015), Mutfakta Tarih-Yemeğin Politik Serüvenleri, İstanbul: İletişim Yayınları, 1. bs.

Özata Dirlikyapan, Jale (2013), Kabuğunu Kıran Hikâye-Türk Öykücülüğünde 1950 Kuşă̆l, İstanbul: Metis Yayınları, 2. bs.

Samanc1, Özge (2012), "Food Studies in Ottoman-Turkish Historiography”, Writing Food History, ed. Kyri W. Kalflin, New York: Berg.

Samancı, Özge (2014), “Avrupa'da ve Türkiye'de Yemek Tarihçiliğine Kısa Bir Bakış”, Mutfakta Tarih Var-Yemek Kültürü ve Tarihçiliği, der. Ayşegül Avc1, İstanbul: Tarih Vakfı Yurt Yayınları, 2. bs.

Sartre, Jean Paul (1995), Bulantı, çev. Erdoğan Alkan, İstanbul: Oda Yayınları, 2. bs.

Sartre, Jean Paul (2018), Varoluş̧̧uluk, çev. Asım Bezirci, İstanbul: Say Yayınları, 28. bs.

Tanpınar, Ahmet Hamdi (1988), 19 'uncu Asır Türk Edebiyatı Tarihi, İstanbul: Çağlayan Kitabevi, 7. bs. 
Tanpınar, Ahmet Hamdi (1997), Tanpınar'dan Hasan-Âli Yücel'e Mektuplar, haz. Canan Yücel Eronat, İstanbul: Yapı Kredi Yayınları, 1. bs.

Tanpınar, Ahmet Hamdi (2013), Hikâyeler, İstanbul: Dergâh Yayınları, 10. bs.

Toptaş, Hasan Ali (2013), Heba, İstanbul: İletişim Yayınları, 1. bs.

Ulutaş, Nurullah ve Ulu, Emine (2015), “Türk Romanında Kimlik Bunalımı”, Turkish Studies, International Periodical For The Languages, Literature and History of Turkish or Turkic, Volume 10/8 Spring, s. 2095-2114.

Yavuz, Hilmi (2018), "Edebiyat ve Sofra” Yemek ve Kültür, Çiya Yayınları, S. 50, Kış, s. 7-8. Yücel, Tahsin (2016), Mutfak Çıkmazı, İstanbul: Can Yayınları, 4 bs. 